\title{
'n Prakties-teologiese besinning oor die begeleiding en toerusting van kinders tot dienswerk as 'n weg tot die navolging van die gesindheid van Christus
}

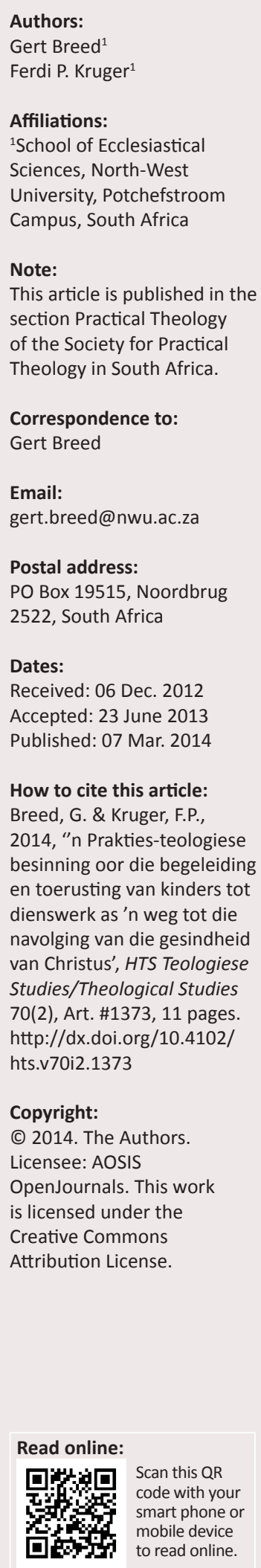

A practical-theological reflection on coaching and equipping children for service as a way to emulating the attitude of Christ. The hypothesis for this research is that the youth is an inherent part of the church. The church, which includes the children, received spiritual gifts from God. The edification of the church is the main purpose in the utilisation of all the gifts. The church received a significant responsibility in equipping and convoying children to be obedient in their calling to be followers of Jesus Christ. Parents and children must use their gifts for their own diakonia. The word diakonia gives expression to the fact that diakonia must take place in accordance to the calling by God. In recent research the expression diakonia also received a more comprehensive meaning. The research field will be explored in four phases and, in doing so, try to come to grips with the current practical-theological situation. In phase one the authors tried to offer a descriptive reflection on research in the practical theology. In phase two the authors undertook exploratory research from the field of the social psychology in order to indicate the prominent role of wrong attitudes and insufficient convoying of children in the praxis. Therefore the authors undertook an intra-disciplinary conversation with the development psychology. In phase three the authors offered basic-theoretical perspectives from Scripture in order to show how the praxis must be. In the last phase of this research practical-theoretical perspectives are explored in order to underline the responsibility of churches in this regard of equipping children in fulfilling their own diakonia. The authors drew a conclusion from their research that children who serve in diakonia and also in obedience to Christ, are also people that are enabled to show the attitude of Jesus Christ towards the world. Parents and other believers must serve in mentoring children. By mentoring children in their diakonia, they enable children and also contribute towards spiritual maturity in their lives.

\section{Inleiding}

Kerkgroei in millennium drie gaan nie oor hoeveel lidmate daar in kerke se lidmaatregisters is nie, maar oor die selfstandige bedienings en aksies wat gelowiges beoefen wanneer hulle die kerkgebou verlaat (Joubert 2009:127). Marshall en Payne (2009:18-20) benadruk dat programgedrewe bediening 'n vername oorsaak is dat die bediening (diakonia) van gelowiges gedemp word. Daarom pleit bogenoemde outeurs in hierdie navorsing dat kerke in hulle bediening op pro-aktiewe wyse sal herbesin oor die toerusting van gelowiges tot diens sodat gelowiges (ook kinders) toegerus en begelei word om gewillig diens te verrig. Smith (2007:129) het vanuit die hoek van die fokusarea van jeugbediening aangetoon dat kinders en jongmense die behoefte het dat hulle lewens waarde het, en daarom soek na 'n plek waar hulle kan dien. Joubert (2009:37) toon op sy beurt aan die hand van 'n empiriese studie aan dat die meeste ontevrede jongmense tussen die ouderdom van 18 en 30 jaar die kerk verlaat. Sewentig persent van die jongmense verlaat teen die ouderdom van 23 jaar die kerk en meer as 34\% van hierdie jongmense keer nie teen die ouderdom van 30 jaar terug na die kerk nie. Een van die vernaamste redes vir hierdie tendens is die negatiewe persepsies wat nie alleen oor die kerk nie, maar ook oor die Christendom bestaan (Joubert 2009:37). Dames (2006:23) beskryf 'n moontlike rede hiervoor, naamlik 'n soeke van kinders en jongmense na geloofwaardigheid. Dit verg jare om geloofwaardigheid by kinders op te bou, maar dit word binne die bestek van minute afgebreek. De Klerk en Dreyer (2007:221) wys daarop dat 'n geloofwaardige kerk kongruensie openbaar in wat hy doen en wat hy is. Joubert (2009:37) benadruk in sy navorsing dat nie-kerklikes meer negatief oor die volgelinge van Jesus is en voel as oor Jesus Christus. Met hierdie stelling bring bogenoemde outeur die belangrike saak van die navolging van Christus na vore wat reeds vroeg aan kinders geleer moet word.

Goheen (2011:51) belig hierdie tendens vanuit die invalshoek van 'n missionale kerk en gee twee redes waarom kerke in dié opsig tekort skiet:

- Afgodery.

- 'n Gebrek aan gewilligheid en vermoë om die inhoud van die geloof aan die volgende geslagte oor te dra (vgl. ook Strommen \& Hardel 2000:1-7). Jongmense spandeer met toestemming 
van hulle ouers baie tyd daaraan om die tegnologie van die tyd baas te raak. Gemeet aan die horisonne en moontlikhede van Facebook, Twitter, die Internet, selfone en allerlei ander programme skiet prediking en kategese tekort vir baie jongmense. Gesinne moet begelei word om aan hulle kinders die noodsaaklikheid van genoegsame tydsbesteding aan die verhouding met God en die waarde van tydsbenutting ten opsigte van hulle dienswerk te benadruk.

Prins (2001:105-106) benadruk in die lig van bogenoemde navorsing die belangrikheid dat die kinders nie as 'n aanhangsel van die kerk beskou moet word nie, maar wel as ' $n$ volwaardige deel van die kerk waarin hulle potensiaal ontsluit word, sodat hulle ook ' $n$ volwaardige rol in die kerk se funksionering as liggaam kan speel. Lincoln (1990:240-241) wys daarop dat gawes aan elke lid van die liggaam gegee is en dat die totaal van hierdie gekombineerde gawes wat die gawes van die jeug insluit, die opbou van die liggaam ten doel het. Roebben (1995:313) benadruk op sy beurt aan die hand van die begrippe geloofwaardigheid en kwaliteitskommunikasie die belangrikheid van die ouerhuise in die kerk. Ouers is immers die primêre agente vir geloofs- en waardevorming (Prins 2001:108).

In die praktiese teologie het $\mathrm{Nel}$ (1982:133-134) op grondige wyse aangetoon dat jeugbediening 'n gedifferensieerde, maar tog toegespitste bediening is wat onderskei kan word in kerugma, didache, paraklese en diakonia. De Klerk en Dreyer (2007:213) voeg by dat selfs goeie kategese nie die kinders en die jeug vir die kerk gaan behou indien bogenoemde vier bedienings nie deel van jeugbediening uitmaak nie (vgl. ook Breed 1994:258). In hierdie artikel maak die outeurs ' $n$ dieptesnit op een van hierdie modi, naamlik die diakonia [diens]. Daar word erken dat ook die ander modi van groot belang is, maar vanweë die veld van ondersoek word volstaan met 'n besinning oor die diakonia. Die begrippe kinders en jeug word in literatuur dikwels as wisselterme gebruik en skep soms verwarring. Die outeurs van hierdie artikel gebruik bogenoemde twee terme ook as wisselterme in dieselfde sin as ander navorsers. Die outeurs stel hulle dit ten doel om aan te toon dat die kerk 'n vername rol het om te speel in die toerusting en begeleiding van kinders om hulle eie dienswerk in navolging van Christus te verrig. Daarom is dit noodsaaklik om enersyds die verantwoordelikheid van ouers aan te toon, maar andersyds ook die belangrike toerustende rol van die kerk as geloofsgemeenskap te belig. In hierdie artikel word aansluiting gevind by die metodologiese lyne van 'n reflektiewe balans wat Osmer (2009:3) vir praktiesteologiese navorsing onderskei het. Osmer (2009:3) het in sy besinning oor ' $n$ hermeneutiese spiraal binne 'n praktiesteologiese ondersoek vier hooflyne onderskei:

- 'n Beskrywend-empiriese ondersoek waarin die navorser inligting versamel om die probleemveld binne die praksis beter te begryp.

- 'n Interpretatiewe ondersoek waardeur die navorser poog om te analiseer waarom sekere handelinge binne die probleemveld geskied. In hierdie artikel sal 'n verkennende ondersoek op interpretatiewe wyse vanuit die sosiale psigologie gedoen word om vas te stel in watter mate verkeerde gesindhede en die gebrekkige erns met begeleiding van ouers en kinders ' $n$ problematiese praksis bewerkstellig. ' $n$ Intra-dissiplinêre gesprek sal op hierdie wyse met die ontwikkelingpsigologie gevoer word.

- 'n Normatiewe ondersoek waarin normatiewe vrae vanuit ander velde van die teologie gestel word. In hierdie artikel sal 'n normatiewe ondersoek gedoen en basisteoretiese perspektiewe vanuit sentrale Skrifgedeeltes ontgin word om spesifiek die betekenis van toerusting tot diakonia te belig.

- 'n Pragmatiese ondersoek waarin die navorser poog om perspektiewe daar te stel om die problematiese praksis te herstel.

\section{'n Beskrywende verkenning van die probleemveld met verwysing na voorbeelde van navorsing op die terrein}

Die afgelope 12 jaar is daar in navorsing op talle aspekte van jeugbediening gefokus. Dit was uit die bronne wat vir hierdie studie geraadpleeg is, dus nie moontlik om een bepaalde fokusarea in die navorsing vas te stel nie. Die volgende aspekte in prakties-teologiese navorsing oor jeugbediening is geag van toepassing te wees op die huidige veld van ondersoek:

\section{Navorsing ten opsigte van die gesindhede van die jeug}

Die gesindhede van die jeug ten opsigte van die kerk het deurlopende aandag in navorsing bly geniet. Pieterse, Dreyer en Van der Ven (2000:53-81) het op die siening gefokus wat by die jeug ten opsigte van Jesus Christus bestaan. Prins (2000:82-100) het op sy beurt op die gesindhede van tieners oor die kerk gefokus. Uit hierdie studie het dit geblyk dat die tieners wat kerklik betrokke was by jeugaksies, meer positiewe gesindhede geopenbaar het as diegene wat nie betrokke is nie. Sweet (2007:20) vestig weer die aandag op die mate waarin gelowige jongmense in die postmoderne lewensuitkyk bereik kan word. Uit die literatuur wat bestudeer is, blyk dit dat die gesindhede van die jeug oor die godsdiens en kerk wêreldwyd akute belangstelling ontlok. Tripp (2007:21-23) het dit op sy beurt benadruk dat alle onderrig en begeleiding van kinders 'n Godgerigte oriëntasie moet openbaar sodat kinders tot 'n deurleefde interaksie met God begelei kan word. Ouers en gelowiges word daardeur as herders geroep om hulle kinders tot navolging van Christus te begelei. Smith (2007:135) het op grond hiervan die gevolgtrekking gemaak dat jongmense wanhopig op soek is na die waarheid, maar dikwels, vanweë afwesige ouers, na strooihalms gryp.

\section{Navorsing oor die voorbeeld wat ouers moet stel as geloofvoorbeelde}

Van Wyk en Venter (2003:533-545) het aangetoon dat die geloofstoerusting van kinders primêr die verantwoordelikheid van ouers is, maar dat dit nooit van geloofsvoorbeelde geskei kan word nie. Kinders moet aan die hand van die voorbeeld 
wat hulle ouers en gelowiges stel, die vreugde van die navolging van Christus bemerk. Sodoende moet kinders leer dat die weg van navolging van Christus meebring dat hulle hul kruis moet opneem en dat hierdie pad nie kinderspeletjies is nie (Joubert 2009:55). Prins (2001:108-109) beklemtoon die rol van ouers in waardevorming by hulle kinders. Tripp (2007:12) vind in die metafoor van ' $n$ herder die rol wat ouers in kinders se lewens moet speel. Nel (2003:152-154) het dit benadruk dat die ouerhuis een van die kernboustene in die verbondsonderrig van kinders is. Uit die navorsing wat op hierdie gebied gedoen is, het dit geblyk dat ouers dit wat hulle in die geloof besit met oorgawe met hulle kinders moet deel (Dreyer \& Kruger 2011:328).

\section{Navorsing oor die rol van die kerk in die geloofsbegeleiding van kinders}

Prins (2001:112-113) het die klem op die noodsaaklikheid van doelbewuste beplanning van buite aan die geloofsbegeleiding van kinders geplaas. Die redes hiervoor, volgens hom, is dat morele vorming deur ouers en die huisgesin nie langer op vanselfsprekende wyse plaasvind nie en dat ouers die saak ook nie langer alleen kan hanteer nie. De Klerk en Dreyer (2007:214) benadruk op hulle beurt die geloofwaardigheid wat aan 'n geloofsgemeenskap as aantrekkingskrag gekoppel moet word. Dit geskied alleenlik indien die vier wesenseienskappe van die geloofsgemeenskap koinonia, verkondiging, liturgie en diakonia in kongruensie met mekaar beoefen word. Dit bring mee dat volwasse gelowiges die gemeenskap van die gelowiges met jongmense moet beoefen en hulle in die kring van gelowiges moet ontvang. Prins (2003:148) spreek die versugting uit dat die bediening aan die jeug aan hulle die hoop soos die Woord dit belowe, sal bedien (vgl. ook Osmer 2001:106-108). De Klerk en Erasmus (2003:91) benadruk in hulle navorsing dat dit in jeugbediening nie daarom gaan om nog 'n ekstra plek vir nog 'n bedieningsmodus te vind nie, maar om vir die jeug 'n plek te vind binne die ruimte en tussen die mense op wie die bedieninge gerig is.

Uit bogenoemde navorsing blyk dit dat die kerk 'n belangrike taak ten opsigte van die begeleiding en toerusting van ouers en kinders het om hulle taak binne die liggaam van Christus te verrig. Een van hierdie opdragte in die begeleiding van die ouers en die jeug is die begeleiding tot diakonia.

\section{'n Interpretatiewe verkenning van die problematiek rondom die toerusting en opleiding van kinders tot dienswerk in hulle navolging van Jesus Christus}

Hierdie artikel wil graag erkenning gee aan die intradissiplinêre benadering ten opsigte van die aangrensende sosiale wetenskappe (Cartledge 2003:15; Pieterse 2001:13). Die praktiese teologie fokus op die handelinge van mense in die konkrete samelewingsverbande en daarom vind oorvleueling plaas met die ondersoekterrein van ander wetenskappe wat op menslike gedrag fokus (Heyns \& Pieterse 1990:14-15). In die ontwikkelingsielkunde, wat die sielkundige ontwikkeling van die mens vanaf bevrugting tot die dood bestudeer en sodoende die totale lewensloop van die mens as veld van ondersoek het, is waardevolle navorsing gedoen oor die leidinggewende rol van ouers en die gemeenskap in die ontwikkeling van kinders se lewens (Duncan 2004:35; Louw \& Edwards 1998:451-453). Vir die doeleindes van hierdie artikel sal op die sosiale en emosionele ontwikkeling van kinders gefokus word.

\section{Perspektiewe op die belangrikheid van gesinsverhoudings}

Die invloed van die ouerhuis is meermale beklemtoon, aangesien nie alleen fisiese behoeftes nie, maar ook belangrike sake soos liefde, sekuriteit en warmte hier gebied word (Louw \& Edwards 1998:470; Louw \& Louw 2007:192). Die ouerhuis is, net soos portuurgroepe, die skool, versorgers en almal met wie die jongmens in interaksie kom, die sosiale omgewing wat deurlopend 'n rol in kinders se lewens speel (Duncan 2004:54). Namate die gehegtheidsdrang van kinders aan ouers ' $n$ wending neem deurdat hulle meer en meer onafhanklik begin funksioneer, tree konflik tussen kinders en ouers in. Alhoewel daar geen resepmatige opvoeding bestaan nie, is daar tog eenstemmigheid oor sekere dimensies van gesonde gesinsfunksionering (Louw \& Louw 2007:194):

- Kinders met warm en versorgende ouers toon oor die algemeen positiewe ontwikkeling op die meeste gebiede. Die warm ingesteldheid van ouers kan in sekere gevalle selfs as buffer dien teen moeilike en nadelige omgewingsfaktore.

- Indien ouers duidelike reëls neerlê en dit konsekwent toepas, is kinders minder geneig om hierdie reëls uit te daag. Hierdie reëls moet verduidelik word sodat almal presies op hoogte sal wees van waarom dit daargestel is. Daar moet dus duidelikheid hieroor bestaan.

- Ouers wat volwassenheidseise (gesonde hoë verwagtings) aan kinders stel, vaar beter, veral wat betref die gevoel van eiewaarde.

- Oop en gesonde kommunikasie wat bereid is om te praat, maar ook te luister, bevorder sosiale volwassenheid van kinders (vgl. Strommen \& Hardel 2000:84-93).

Saam met bogenoemde dimensies van interaksie speel ouerskapstyl volgens Louw en Louw (2007:194-195), en Louw en Edwards (1998:471) 'n vername rol. Die volgende ouerskapstyle kan volgens bogenoemde outeurs onderskei word:

- Die gesaghebbende ouerskapstyl. In hierdie styl is ouers betrokke by hulle kinders, maar word daar duidelike perke gestel. Hierdie ouerskapstyl stel grense en perke, maar moedig tegelyk ook onafhanklikheid aan.

- Die outoritêre ouerskapstyl. Hierdie styl kom koud voor, aangesien kinders maklik verwerp voel vanweë afjakke en kritiek. Ouers wat hierdie styl volg, wil graag beheer uitoefen, maar doen dit deur te skree en te baklei. Kinders wat hieraan blootgestel word, is gevolglik geneig om die ouers uit te tart. 
- Die permissiewe ouerskapstyl. Hierdie styl word gekenmerk deur ouers wat wel warm en aanvaardend is, maar hulle is ontoegeeflik en onoplettend. Kinders word gedwing om besluite oor sake te neem waarvoor hulle nog nie gereed is nie. Hierdie ouerskapstyl lok impulsiwiteit en opstandigheid by kinders uit. Kinders wat uit hierdie huise kom, sukkel om te volhard in dinge wat aangepak word.

- Die onbetrokke ouerskapstyl. Ouers met hierdie styl is geneig om emosioneel afsydig te wees as gevolg van hulle eie onverwerkte probleme. In die toepassing van hierdie styl het die ouers min tyd en energie oor vir die behoeftes van hulle kinders. Kinderverwaarlosing is die uiterste pool van hierdie ouerskapstyl.

Die wisselwerking tussen die ouerskapdimensies en ouerskapstyle kan skematies soos in Figuur 1 voorgestel word (vgl. Louw \& Louw 2007:195).

Wood en Wood (1999:315) beskryf die taak van ouers as sosialiseringsagente aan die hand van die begrippe modellering, onderrig, voorsien en dissipline. Bogenoemde outeurs beskryf die psigososiale ontwikkeling vroeg in kinders se lewens wat bepalend is vir hulle vermoë en bereidwilligheid om later in hulle lewens hulle diakonia te verrig aan die hand van navorsing wat vroeër op grondige wyse deur Erikson gedoen is. In hierdie navorsing is dit belangrik om daarop te let dat nie alleen die ouerhuis nie, maar ook die kerk as sosialiseringsagent bewus sal wees dat daar rekening met die leeftydfases van kinders en jongmense gehou moet word. Tabel 1 gee volgens Wood en Wood (1999:315) asook Louw en Edwards (1999:472) iets weer van die uitdaging ten opsigte van jeugbediening.

\section{Perspektiewe op die morele ontwikkeling van kinders}

Gedurende die kinderjare en veral gedurende adolessensie, is die ontwikkeling van moraliteit 'n noodsaaklike verantwoordelikheid van sosialiseringsagente (Woolfolk

\begin{tabular}{|c|c|c|c|}
\hline \multicolumn{4}{|c|}{$\begin{array}{l}\text { Struktuur en leiding } \\
\text { (beheer en eise) }\end{array}$} \\
\hline \multirow{3}{*}{ 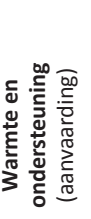 } & \multirow{3}{*}{ 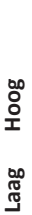 } & Laag & Hoog \\
\hline & & Permissief, toegeeflik & Outoritatief, wederkerig \\
\hline & & Onbetrokke, nalatig & Outoritêr \\
\hline
\end{tabular}

FIGUUR 1: Ouerskapdimensies en ouerskapstyle.
2007:98). Morele ontwikkeling verwys na die proses waar kinders aan die hand van beginsels of idees begelei word om tussen reg en verkeerd te onderskei en hulle gedrag daarvolgens te rig (Louw \& Louw 2007:208). Kinders moet volgens Duncan (2004:55) aanleer om skaam te wees as hulle reëls oortree en om die neiging te onderdruk om 'verbode dinge' te doen. Sodoende word die deug van selfbeheersing ingeoefen. Kinders moet van vroeg geleer word om 'n morele redenasievermoë te openbaar (Baron \& Byrne 1994:87; Louw \& Edwards 1999:485). Die tempo van morele redenasievermoë word egter beïnvloed deur die sosiale konteks waarin kinders lewe. Kinders in komplekse stedelike kulture word vinniger gekonfronteer met belangrike kwelvrae wat die morele redenasievermoë aan eise onderwerp (Louw \& Edwards 1998:485). Woolfolk (2007:101) het aangetoon dat kinders en jongmense wat hierdie morele redenasievermoë aangeleer het, meer geneig is om uit te reik na ander mense en hulle by te staan en te help.

Louw en Edwards (1998:485-486) benadruk veral drie faktore wat 'n primêre rol speel om morele verantwoordelike gedrag by adolessente te bevorder:

- Aanmoediging en toerusting tot sosiale verantwoordelikheid en selfbeheersing.

- Volwasse rolmodelle van ouer persone en ouers is iets waarna jongmense graag opkyk.

- Die skep van geleenthede vir jongmense om morele dilemmas en beginsels te bespreek.

Sosialiseringsagente moet kinders begelei om aan die hand van voorbeelde te sien en te verstaan wat reg is, sodat internalisering van waardes kan plaasvind en sodat jongmense kan begryp hoedanig daardie waardes hulle in hulle totale menswees en selfbeeld raak (Woolfolk 2007:102). Kinders moet dus nie net die inhoud van die onderrig geleer word nie, maar ook die hoekom, sodat hulle die onderrig hulle eie kan maak. Die hoofdoel van die begeleiding is immers dat kinders en jongmense dit wat aan hulle oorgedra is, deel van hulself kan maak. Wood en Wood (1999:329) benadruk die drie vlakke en ses stappe waarvolgens morele ontwikkeling by mense geskied:

- 'n Pre-konvensionele vlak (4-10 jaar) waar morele redenasievermoë afhanklik is van die gevolge (beloning of straf). Die eerste twee stappe vind op hierdie vlak plaas, naamlik kinders is gehoorsaam uit vrees vir straf en hulle stel belang in die voordeel wat hulle uit 'n saak kan trek.

- Die konvensionele vlak (10-13 jaar). Kinders internaliseer die standaarde van ander en beoordeel dinge aan die

TABEL 1: Die uitdaging ten opsigte jeugbediening.

\begin{tabular}{lll}
\hline Fase & Ouderdom & Beskrywing \\
\hline $\begin{array}{l}\text { Vertroue teenoor wantroue } \\
\begin{array}{l}\text { Selfstandigheid teenoor skaamheid en } \\
\text { twyfel }\end{array}\end{array}$ & $\begin{array}{l}\text { Geboorte tot 1 jaar } \\
\text { Inisiatief teenoor skuldgevoelens }\end{array}$ & $\begin{array}{l}\text { In hierdie fase leer kinders om te vertrou of te wantrou. Die ouerskapstyl is bepalend. } \\
\text { Kinders leer in hierdie fase om keuses te maak, en indien dit nie goed genoeg is nie, leer hulle skaamte en twyfel } \\
\text { aan. }\end{array}$ \\
$\begin{array}{ll}\text { Industrie teenoor minderwaardigheid } \\
\text { Kinders leer om sekere take aan te pak en af te handel. Indien dit nie aangemoedig word nie, ontstaan } \\
\text { skuldgevoelens. }\end{array}$ & $\begin{array}{l}6 \text { jaar tot in puberteit } \\
\text { Identiteit teenoor rolverwarring }\end{array}$ & $\begin{array}{l}\text { Kinders wil graag take aanpak en afhandel. Hulle wil graag dinge doen. Indien hulle nie toegelaat word om dit te } \\
\text { doen nie, ontstaan gevoelens van minderwaardigheid. }\end{array}$ \\
\hline
\end{tabular}


hand hiervan. Die volgende twee stappe vind nou plaas. Kinders doen graag dinge om ander gelukkig te maak en hulle te help, en die belangrikheid van orde word in 'n volgende stap gevestig.

- Die post-konvensionele vlak (na ouderdom van 13). 'n Morele lewenswyse is geïnternaliseer. In stap 5 en 6 word respek vir ander mense se belange en regte, asook die belangrikheid van etiese beginsels gevestig.

Bogenoemde navorsing benadruk die noodsaaklikheid van die begeleiding en voorbeeld van ouer persone en die huisgesin. Kerke moet toenemend kennis neem van die groot verantwoordelikheid wat hulle in jeugbediening oor hierdie saak van morele redenasievermoë het.

\section{Perspektiewe op die vorming van gesindhede by die jeug}

Fiske (2004:216-217) beskryf gesindhede as strukture wat in die geheue van mense gestoor word. Baron en Byrne (1994:138) toon aan dat hierdie struktuur van gesindhede uit drie komponente of geledinge bestaan, naamlik 'n kognitiewe komponent (oortuigings), 'n affektiewe komponent (evaluering of emosies) en 'n handelingsmoment (voornemens). 'n Verandering in een van die komponente lei tot 'n verandering in die ander komponente (Lord 1997:231). 'n Gesindheid is dus die algemene gevoel (wat wissel van goed tot sleg) wat 'n persoon teenoor, hulleself, ander mense, voorwerpe of gebeure het (Louw \& Edwards 1998:704). Daar is dus rigting, sterkte en sentraliteit in gesindhede. Gesindhede wat uit eie en direkte ervaring opgebou word, is baie sterk en oefen 'n groot invloed op jongmense se lewens uit (Baron \& Byrne 1994:136).

Fiske (2004:227-228) toon aan dat gesindhede deur 'n sosiale proses van waarneming van ander persone aangeleer word. Kinders en jongmense neem waar wat ouer persone doen en hoe hulle optree. Die voorbeeld wat van vroeg gestel word, speel 'n rol in die vorming van gesindhede. Duncan (2004:277) toon aan dat die ouderdom 12-30 jaar 'n kritieke tydperk in die vorming van gesindhede is. Drie sake speel in dié tydperk 'n rol:

- Die invloed van mense met dieselfde ouderdom en opvoeding met wie maklik geassosieer word. Die sienswyses van die verwysingsgroepe is belangrik vir jongmense. Portuurgroepe skep gevoelens van sekuriteit en help dikwels om ouers te vervang en skep sodoende geleenthede om te eksperimenteer.

- Die toeganklikheid tot kommunikasienetwerke verswak ouers se invloed.

- Nieteenstaande bogenoemde twee faktore bly opvoeding en toerusting van die belangrikste boustene in die gesindheidsvorming.

Boshoff (1985:1-10) benadruk dat die veranderinge in die land en die wêreld ook ' $n$ invloed op kinders se lewens het. Jongmense ervaar dat 'n breuk van sekerhede plaasvind, wat dikwels nog meer intens word vanweë ouers se oorvol program en die geborgenheid van die huisgesin wat vanweë gesinsdisorganisasie onder skoot kom. Genoemde outeur bemerk 'n gesindheidsverandering as gevolg hiervan, waarvan geloofsgemeenskappe kennis moet neem. Vier groot verskuiwings in gesindhede het volgens Boshoff (1985:3) plaasgevind:

- Die proses van individualisme het meegebring dat onswaardes verander het, met die klem al hoe meer op die 'ek'. Jongmense wil daarom graag bedien word as individue met eie behoeftes.

- Die opkoms van die situasie-etiek stel uitdagings aan die bediening. Min dinge is absoluut reg of verkeerd vir jongmense.

- 'n Eksistensiële lewenshouding waar die klem op 'n ekwil-die-lewe-geniet-gesindheid val, is dikwels belangrik vir jongmense.

- Die opbloei in die ervaring en gevoelgedrewe godsdiens het die bediening ook voor uitdagings te staan gebring.

Prins (2000:82-90) het navorsing gedoen oor die godsdienstige gesindhede van jongmense waarin hy wou vasstel wat jongmense se gesindheid teenoor God is, en ander lewensverbande. Uit die navorsing het geblyk dat kinders ongeveer teen die ouderdom van 13 jaar, met die oorgang na die vermoë om abstrak te kan dink, die behoefte ervaar om hulle verhouding met God met hulle alledaagse lewe te kan verbind. Die rol van die makkergroep, en vriende wat deel van die jeugbediening in die gemeente uitmaak, dien as magneet vir eie betrokkenheid. Jongmense ervaar toenemend dat gebrekkige warmte in gemeentes dit vir hulle moeilik maak en dat die atmosfeer tydens eredienste hulle nie aanstaan nie. Kinders en jongmense ervaar 'n sterk behoefte om verhoudings met leraars en gelowiges te bou (Prins 2000:98).

Humphrey en Stokes (2000:314) het oorredende kommunikasie uitgewys as 'n effektiewe wyse waarop verkeerde gesindhede verander word. Eagly en Chaiken (1993:113) het egter aangetoon dat alle mense 'n natuurlike geneigdheid het om hulle teen oorredingskommunikasie te verset, en het juis daarom die noodsaaklikheid om toepaslike inligting te verskaf bepleit. Baron en Byrne (1994:152) beklemtoon daarom die feit dat, indien daar ' $n$ wederkerige verhouding tussen die oorreder en die persoon wat oorreed word, bestaan, die oorredingsproses meer effektief is.

\section{Samevattende perspektiewe op die rol van ouers en die geloofsgemeenskap in die begeleiding van jongmense}

Vanuit bogenoemde beredenering kan die volgende samevattende perspektiewe gebied word:

- Ouers bly primêr verantwoordelik vir die opvoeding en geloofstoerusting van hulle kinders tot navolging van Jesus Christus. Kinders groei tot onafhanklikheid van hulle ouers en word later ook blootgestel aan ander sosialiseringsagente. In hierdie opsig kan 'n geloofsgemeenskap baie waarde toevoeg deur ouers en kinders tot geloofsgroei te begelei. 
- Ouers moet toegerus word om ook in hulle ouerskapstyl hulle kinders met die nodige toewyding te begelei sodat daar by die kinders die vrywilligheid sal bestaan om met vrymoedigheid te dien. Ouerskapstyl moenie in die weg van die bereidheid tot diens staan nie.

- Jongmense moet die geleenthede gebied word om in hulle gemeentes 'n morele redenasievermoë aan te leer. Geleenthede om ander gelowiges met hulle insig te kan bedien moet ook geskep word.

- Gesindhede word reeds op vroeë ouderdom gevorm. Baie van hierdie gesindhede beïnvloed ook die gedrag van jongmense. Negatiewe gesindhede teenoor die kerk en medegelowiges dien as ' $\mathrm{n}$ hindernis en struikelblok vir dienswerk. Gemeentes moet hulle vergewis van hoe gesindhede gevorm word en wat die omvang daarvan behels.

- Oorredingskommunikasie word allerweë bestempel as 'n geldige wyse waarop verkeerde gesindhede verander kan word. Dit bring mee dat die rol van die kerk as kommunikatiewe gemeenskap optimaal ingestel moet wees om die regte dinge te kommunikeer.

- Die kerk het die taak as sosialiseringsagent om saam met die ouers die ruimte aan kinders te bied om van kleins af geleenthede te kry om te dien.

- Jongmense het die behoefte om verhoudings met hulle geestelike leiers en ouer mense te bou.

\section{Praktyk-teoretiese besinning oor die begeleiding en toerusting van ouers en kinders tot diakonia}

In hierdie deel van die artikel oor praktyk-teoretiese perspektiewe word op een aspek van die toerusting van ouers en kinders, naamlik die diakonia van elke gelowige, gefokus. Hiermee word die vierde taak van navorsing volgens Osmer ook aangeraak. Dit is belangrik dat op die diakonia gefokus word, aangesien nuwe navorsing oor die betekenis van die diakon-woordgroep (Arndt, Danker \& Bauer 2000; Breed 2012b; Collins 1990, 1995, 2002a, 2002b, 2005, 2010; Gooder 2006; Haire \& Watson 2003:40-51; Hentchel 2007; Latvus 2008, 2010; Van Klinken 1989) ingrypende betekenis vir die totale bedieningspatroon van die gemeente, en in die besonder vir die toerusting van ouers en kinders, kan hê.

Die betekenis van die diakon-woordgroep is dikwels in die verlede beperkend beskou asof dit in die Nuwe Testament net uitdrukking sou gee aan die begrip van nederige dienswerk of barmhartigheidsdiens, of ook die werk van 'n kelner (Gooder 2006:2, 3; Latvus 2008:144). Wanneer die gebruik van hierdie woordgroep in die Nuwe Testament bestudeer word, word dit egter duidelik dat dit ' $n$ wye verskeidenheid betekenisvelde verteenwoordig, wat telkens uit die verband waarin dit staan, bepaal moet word (Latvus 2008:148). Die woord diakonos beskryf telkens iemand aan wie ' $n$ bepaalde opdrag gegee is as verteenwoordiger van die persoon wat hom of haar gestuur het. Diakonia druk dienswerk uit wat in ooreenstemming is met die roeping wat iemand ontvang het (Kruger 2005:535). Hierdie woordgroep beskryf ook die volle dienswerk van die gemeente. So word die dienswerk (diakonia) in die gemeente in Handelinge 6 ter wille van effektiwiteit verdeel. Die apostels neem een deel van die diakonia waarop hulle gaan konsentreer, en aan die sewe manne wat verkies word, word die res van die diakonia opgedra (Breed \& Breed 2010:635, 636). Verskeie persone in die Nuwe Testament word aangedui as 'n diakonos (Rom 15:8; Ef 3:7; Ef 6:21; Kol 1:7; Kol 1:23; Kol 1:25; Kol 4:7; 1 Tess 3:2; 1 Tim 4:6). Op twee plekke (Fil 1:1 en 1 Tim 3:8,12) is dit duidelik dat daar leiers in die gemeente was wat met die begrip diakonos aangedui word. Nêrens word die presiese inhoud van hulle dienswerk egter beskryf nie (Breed 2012b:4, 5; Latvus 2008:147-149).

Navorsing oor jeugbediening fokus dikwels op die bediening van die kinders en jeug, en die bediening deur die kind en jongmens kry dan min aandag (vergelyk die volgende werke wat omvattend handel oor jeugbediening en navorsing daaroor, maar nie die plek van die begeleiding tot dienswerk in diepte aanraak nie: Dunn \& Senter 1997; Mueller 2006, 2007; Strommen \& Hardel 2008). Ander (Robins 1990:217-230; Strommen \& Handel 2001:181-198) wys wel op die belangrikheid van toerusting tot dienswerk, maar konsentreer op praktiese wenke of statistiese gegewens met gebrekkige Bybelse begronding. Robins se omvattende werk oor jeugbediening (2004:387-402) handel oor 'true spirituality'. Wanneer hy egter die tema bespreek van geloof wat tot dade moet oorgaan, beperk hy dit tot die persoonlike lewe van die tiener en raak nie die betekenis van diakonia soos in die Bybel verwoord, aan nie. Ander skrywers fokus wel op die opdrag aan die kind om aan dienswerk deel te neem. Dingemans (1991:63) verwys na die sentripetale en sentrifugale bewegings in kinderbediening en plaas die klem op die wisselwerking tussen die toerusting en die missionêre gerigtheid van die aanwending van kinders se gawes. Genoemde outeur gee daardeur die perspektief dat gawes wat tot eer van God aangewend word, ook daartoe moet lei dat kinders God se sending in hierdie wêreld (Missio Dei) word. Kennedy (2004:53) wys op die 4-14-vensterbeweging se klem op die kind se roeping om ander kinders te evangeliseer. Nie een van hierdie skrywers benader kinderen jeugbediening egter vanuit die perspektief van die nuutste navorsing oor die diakon-woordgroep nie.

Hierdie deel van die artikel wil hierdie leemte bespreek deur die resultate van die nuutste navorsing oor die diakonwoordgroep op kinder- en jeugbediening toe te pas. Die volgende betekenisinhoude van die diakon-woordgroep is van belang vir die toerusting van kinders.

\section{Diakonia as die bediening van God se genade, moontlik gemaak deur die genadegawes van die Gees}

In Efesiërs 4:12-16 word gesê dat die hele gemeente toegerus behoort te word vir hulle diakonia [dienswerk] (Kruger 2005:540, 541). Kruger (2005) toon oortuigend aan dat hierdie toerusting deel uitmaak van ' $n$ wordingsproses van sowel elke lidmaat as die hele gemeente. Uit 1 Korintiërs 
12:4-6 is dit duidelik dat die genadegawes wat die Gees gee, bedoel is om tot dienswerk (diakonia) te lei, sodat die krag van God daardeur in die gemeente en die wêreld effektief kan werk (Breed 2012c; Du Plessis \& Breed 2013:5, 6). In 1 Petrus 4:10 word gesê dat die gelowiges bestuurders van God se veelvuldige genade is. Elkeen ontvang genadegawes waardeur God se genade aan mekaar bedien (diakoneo) moet word. God se genade en genadegawes moet dus op die diakonia van die gemeente uitloop. Die diakonia maak die genade effektief in die lewe van ander mense (Feldmeier 2008:218220). Die diakonia word in 1 Petrus 4 nou verbind met die regering van Christus (Janse van Rensburg 2011:3). Dit sou ook andersom verwoord kan word: Indien die genadegawes wat die gemeente ontvang, nie gebruik word om ander te bedien (diakoneo) nie, is hulle ontroue bestuurders van God se genade en kan dit wees dat hulle die kragtige werking van God se genade, soos dit in die regering van Christus na vore kom, misloop (Dunn 2006:554; Du Plessis \& Breed 2013: 5, 6).

Dit is belangrik om hier te sê wat onder genadegawes verstaan word. Genadegawes is gawes wat Christus, as oorwinnaar oor die bose, aan sy gemeente gee (Ef 4:7-11) deur die werking van sy Gees (1 Kor 12:4-11) (vgl. Kruger 2005:535-537). Alleen diegene wat bely dat Jesus die Here (oorwinnaar, koning, eienaar) is, het die Gees van God in hulle (1 Kor 12:3). Die Gees deel aan dié wat Jesus as Here bely, die gawes uit soos wat nodig is vir die opbou van die gemeente. Daar is 'n verskeidenheid gawes. Hierdie verskeidenheid gawes gee aanleiding tot ' $n$ verskeidenheid bedieninge (diakonia, 1 Kor 12:5). Elke bediening is nodig binne die gemeente en elkeen bediening het die ander se bediening nodig (1 Kor 12:12-26) (Dunn 2006:551-552). Gawes sluit nie net besondere vermoëns in nie, maar ook besondere geleenthede (roeping) waarin iemand deur die Gees gestel word (1 Kor 12:18). Ouers ontvang binne die gemeente ' $n$ besondere plek wat hulle in staat stel om op 'n unieke manier met hulle eie kinders te werk (Bunge 2008:351). Die gemeente staan ook in ' $n$ besondere verhouding tot die kinders en jongmense in die gemeente, wat hulle die geleentheid gee om hulle op ' $n$ unieke wyse te bedien. 'n Vroeër seksie van die artikel wat fokus op die perspektiewe oor die aanleer van groter aktiwiteit ten opsigte van dienswerk, is aangetoon dat gemeentes die ruimte vir kinders moet skep om diensbaar te kan wees.

Uit voorafgaande wisselwerking tussen die perspektiewe vanuit die Skrif en perspektiewe vanuit die ontwikkelingsielkunde kan die volgende afgelei word:

- Kinders moet toegerus word met kennis van die drie-enige God soos Hy Hom in sy Woord openbaar (1 Kor 12:4-6).

- Kinders en jongmense moet begelei word om, onder leiding van die Gees, in opregtheid Jesus as hulle Here met woord en daad te bely. Hierdie belydenis mond uit in 'n lewe waarin voortdurend met die sonde gebreek word (1 Kor 12:1-3; Ef 4:1, 17-24; 1 Pet 4:1-19).

- Kinders en jongmense is deel van die gemeente; hulle het elkeen ook gawes van die Gees ontvang (1 Kor 12:7; Ef 4:16).

- Kinders en jongmense se gawes is noodsaaklik vir die opbou van die gemeente. Die gemeente moet dit besef en dit deur die wyse waarop die totale bediening aangepak word, aan die kinders oordra dat die gemeente hulle nodig het (1 Kor 12:11-22).

- Kinders en jongmense moet só bedien word dat hulle begryp dat hulle die bediening van medegelowiges nodig het (1 Kor 12:21).

- Indien daar nie ruimte geskep word dat kinders en jongmense hulle gawes in dienswerk laat oorgaan nie, word die liggaam armer en word die groei van die liggaam daardeur gestrem (Ef 4:11-16).

- Christus se regering word deur die diakonia effektief in die kind se lewe en in die lewens van dié wat hy dien (1 Pet 4:10).

- Kinders en jongmense moet begelei word om te begryp dat hulle bestuurders van God se ryke genade is en dat Hy sy gawes aan hulle gee sodat hulle sy genade deur hulle diakonia aan ander kan bedien (1 Pet 4:10).

- Kinders en jongmense moet doelgerig toegerus word om die gawes wat die Gees aan hulle gee, te ontdek en te gebruik (Ef 4:11-16). Hiervoor moet daar doelbewus geleenthede geskep word waar kinders en jongmense saam met die gemeente dienswerk kan doen. Kinders moet verantwoordbaar gehou word om hulle gawes tot diens van ander te gebruik.

- Ouers moet toegerus word om die roeping van God vir hulle eie kinders te begryp en te soek na die gawes van die Gees waarmee Hy hulle sal toerus om hierdie roeping te vervul.

- Ouers moet saam met hulle kinders by dienswerk betrokke raak. Ouers en kinders moet toegerus word om hulle spesifieke dienswerk met vrymoedigheid te kan doen. Hierdie toerusting moet deeglike prinsipiële toerusting insluit, maar ook begeleiding deur 'n ervare persoon om die teorie praktyk te maak (De Vries 1997:500).

- Die opvoeding van hulle kinders is die unieke toegespitste diakonia wat die Here aan ouers toevertrou. Hiervoor moet hulle deur die gemeente verantwoordbaar gehou word.

- Die gemeente moet enkel-ouergesinne of gesinne met ander probleme bystaan in die opvoeding van die kinders.

\section{Diakonia as die bediening van God se genade in opdrag van, in gehoorsaamheid aan en in afhanklikheid van God}

Wanneer Jesus die doel van sy koms na die aarde beskryf, sê $\mathrm{Hy}$ onder andere dat Hy nie gekom het om gedien (diakoneo) te word nie, maar om te dien (diakoneo) en sy lewe as losprys te gee vir baie (Mark 10:45). Op ander plekke sê Hy dat Hy net kom doen het waarvoor die Vader Hom gestuur het (Joh 12:49, 50). Hy beskryf ook die oortuiging dat Hy deur die Vader gestuur is as 'n kerndeel van sy dissipels se geloof (Joh 17:8). Dit kan dus met reg gesê word dat Jesus se diakonia die bediening van God se genade aan die mens is om hulle nood (slawerny van die sonde en die gevolge daarvan) aan te spreek.

Volgens Filippense 2 vloei hierdie diakonia van Christus voort uit 'n bepaalde gesindheid (2:5) (Bruce 2011:35). Die gesindheid word duidelik daarin dat $\mathrm{Hy}$, in gehoorsaamheid 
aan sy Vader, sy bestaan op Godgelyke wyse nie beskou het as iets waaraan Hy Hom moes vasklem nie, maar dat $\mathrm{Hy}$ Homself verneder het en ' $n$ mens geword het en Homself daarna tot die dood aan die kruis verneder het (2:6-8). Sy dienswerk (diakonia) het ingehou dat Hy alles wat nodig was tot redding van baie sou doen en so die genade van God aan hulle bedien (Silva 2005:92-97). Saam met die voltooiing van sy dienswerk het sy verheffing gegaan. Hy is tot die hoogste eer verhef en uiteindelik sal elke knie voor Hom buig en elke tong sal bely dat Jesus die Here is (2:9-11). In vers 5 word gesê dat dieselfde gesindheid in die gelowige moet wees. Die gesindheid is dat die gelowige bereid moet wees om die plek van veiligheid en sekuriteit prys te gee en op te offer wat ook al nodig is om tot die redding van ander te dien. Die praktyk van hierdie offer word in vers 3 en 4 uitgespel, naamlik dat die gelowige nie in selfsug vir homself of haarself moet probeer sorg nie en ook nie daarop uit moet wees om eer te ontvang nie, maar dat hulle ander hoër moet ag as hulleself en ook aan ander se belange moet dink. Dit kan die gelowige doen vanuit die sekerheid van die versorging van die drieenige God (2:1) (Bruce 2011:33).

Wanneer Skrif met Skrif vergelyk word, is dit duidelik dat Paulus hier (Fil 2:1-11) die opdrag wat Jesus volgens Markus 10:43, 44 aan sy dissipels gegee het, op die gemeente van Filippi toepas Jesus sê volgens Markus 10:43, 44 vir die dissipels dat hulle nie soos die wêreldse leiers oor mekaar moet probeer heers nie, maar dat 'n volgeling van Jesus die ander se dienskneg (diakonos) moet word; dan sal hy groot wees onder hulle. Beide aspekte van diensbaarheid en die verheffing deur God van die een wat bereid is om homself te verneder, word sowel in Markus 10 as Filippense 2 beklemtoon (Asumang 2012:8, 9).

In Johannes 12:25, 26 betrek Jesus sy dissipels by die uur van sy dood en sê aan hulle die een wat Hom wil dien (diakoneo), moet Hom volg en bereid wees om soos $\mathrm{Hy}$ in gehoorsaamheid aan die opdrag van die Vader te sterf sodat die kinders van God gered kan word. In vers 27 spreek Jesus sy eie worsteling uit vanweë die lyding wat hierdie uur van Hom gaan vra. Sal Hy vra om van die uur verlos te word? Hy kom egter tot die konklusie dat die lydensuur die doel van sy koms na die aarde is. Dan vra Hy die teendeel: 'Vader, verheerlik U Naam.' Hiermee kies Hy om sy Vader te gehoorsaam en met sy dienswerk die verlossing te bewerk, wat dit ook al van Hom vra. Dit is waarin elke diakonos Hom moet navolg: hierdie keuse vir God, deur die diakonia wat Hy aan jou opdra, te doen ongeag die offer wat dit vra. In Filippense 2 loop die oproep aan die gemeente om in die gesindheid van Christus te leef uit op die oproep om uit eie beweging met vreugde aan God gehoorsaam te wees, al sou dit ook lyding meebring (2:12-18) (Breed 2012c).

Uit die brief van Jakobus is dit duidelik dat geloof sonder werke dood is (2:14-26). Groeschell (2010:15) noem iemand wat nie sy geloof uitleef nie ' $n$ Christen-ateïs. Uit 2 Timoteus 3:16, 17 is dit duidelik dat die uiteindelike doel van die onderrig uit die Skrif is dat iemand toegerus sal wees vir elke goeie werk. In Efesiërs 2:10 word bevestig dat God ons uit genade wederbaar sodat ons goeie werke kan doen. In
Matteus 25:35-44 word 'n gelykenis van Jesus verhaal. Die oordeel of iemand die ewige lewe ontvang, word hier gevel op grond van die antwoord op die vraag of jy Jesus gedien (diakoneo) het deur jou oor ander te ontferm. Diegene wie se geloof nie tot diakonia oorgegaan het nie, het daardeur getoon dat hulle nie 'n ware geloof gehad het nie.

Wanneer kinders en jongmense nie doelgerig toegerus word om hulle gawes te gebruik in hulle diakonia nie, word hulle mislei. Nie alleen is hierdie toerusting onvolledig nie, maar hulle word aktief geleer dat geloof sonder werke wel 'n ware geloof is, wat dit nie is nie. Dikwels is kerke verbaas dat kinders na jare van kategese die kerk verlaat en nooit terugkeer nie. Dieselfde kerke het egter van kleins af vir die kinders geleer dat jy maar net Sondag kan kom en jou katkisasie-antwoorde kan gee; verder vra God niks van jou nie (vgl. Grobbelaar 2008:161). Dikwels bestaan die kinder- en jeugaksies slegs uit vermaak en intellektuele godsdienstige gesprekke (Dean 2010:25-42); daar is geen doelgerigte diensaksies waar die kind begelei word om volhardend in gehoorsaamheid aan God die diakonia van Christus aan mense te bedien nie. Hulle word nie voor die toets gebring of hulle bereid is om hulleself as lewende en heilige offers aan God te gee nie (Rom 12:1-4), al sou dit vra dat hulle hulle lewe in diens van hulle Vader moet verloor (Strommen \& Hardel 2008:153-157).

Kinders moet doelbewus aan die praktyk van diakonia blootgestel word sodat hulle verstaan dat geloof eers ware geloof is wanneer dit geleef word. Hulle moet voor die keuse gestel word om te waag om hulleself te verneder in vertroue dat hulle Vader hulle sal verhoog. Hierin is daar niemand wat die kind so voortdurend en intiem kan onderrig as die ouer wat elke dag saam met hom leef nie (Bunge 2008:355). Die kind moet die ouers se pad van val en opstaan in hulle strewe om tot volkome oorgawe aan die Gees te kom, sien. Hulle moet saam met hulle ouers dien, saam die teleurstellings en pyn, maar ook die sukses en oorwinnings wat saam met die diakonia kom, ervaar. Filippense 2 dui aan dat die pad na eenheid (2:2), ook in die gesin, die pad van diensbaarheid aan mekaar vanuit die troos, liefde en gemeenskap van die drie-enige God is (2:1). Só groei die gesindheid van Christus in elkeen wat dit doen (2:5). Die toerusting van ouers om hulle kinders te dien soos hulle deur Christus gedien is, is ' $n$ belangrike deel van die begeleiding van die kind tot diakonia. Wanneer die kind dan die ouers in hulle diakonia vanuit die sekerheid van die diakonia van die drie-enige God navolg, groei die gesindheid van Christus nog verder in hulle (vgl. Bunge 2008:354, 355).

Indien 'n gemeente diakonia as 'n noodsaaklike uitvloeisel van 'n ware geloof verkondig, sal ouers en kinders en elkeen wat by hulle betrokke is, tot ' $n$ ernstige herbesinning oor hulle prioriteite in die lewe begelei moet word. 'n Gemeente wat toelaat dat lidmate se geloof nie tot dienswerk oorgaan nie, werk mee daaraan dat die genade van God nie kragtig binne die individue, gesinne en die gemeente werk nie (Hendriks \& Grobbelaar 2009a:350, 351). Indien ouers nie tyd bestee om hulle kinders aktief te bedien nie, beroof hulle die kinders van die genade wat God vir hulle bedoel het. Indien ouers nie 
saam met hulle kinders dienswerk doen nie, beroof hulle die kinders van die kragtige invloed wat God deur ervaring en voorbeeld aan die kinders wil gee. Die genade van God word nie vir die kind 'n werklikheid nie. So 'n gemeente is besig om die genade van God te wanbestuur en moet nie verbaas wees wanneer jongmense hulle genade op ander plekke gaan soek nie (Hendriks \& Grobbelaar 2009b:360, 361, 365, 366).

\section{Die noue band tussen diakonia en verheerliking}

Die diakonia van die gelowige is dienswerk onder leiding van die Gees van God. Dit is dienswerk in opdrag van God waaroor uiteindelik verantwoording teenoor God gedoen moet word (Latvus 2008:148, 149). Diakonia vra van die gelowiges bereidheid om hulle lewe prys te gee in diens aan God. Diakonia word egter ook gedoen met die versekering dat God sy dienskneg eer. Dit word duidelik uit Jesus se woorde wat in Johannes 12:26 opgeteken is:

As iemand My dien (diakoneo), laat hom My volg; en waar Ek is, daar sal my dienaar (diakonos) ook wees; en as iemand My dien (diakoneo), sal die Vader hom eer.

In die evangelie van Johannes word die uitvoering van die taak wat jy ontvang het, telkens verbind met die eer wat jy van die Vader ontvang, maar ook dat jy die Vader deur jou dienswerk verheerlik. Jesus noem die uur van lyding wat nou vir Hom gaan aanbreek, die uur van sy verheerliking. Sy besluit om te doen waarvoor Hy gestuur is, druk Hy uit met die woorde: 'Vader, verheerlik U naam' (Joh 12:28). Volgens Johannes 17:1 vra Jesus die Vader om Hom te verheerlik sodat Hy die Vader kan verheerlik. Hy sê ook (17:4) dat Hy die Vader verheerlik het deur die taak wat Hy ontvang het, te volvoer, en Hy vra die Vader om Hom te verheerlik met die heerlikheid wat Hy voor die skepping van die aarde gehad het (17:5). Jesus gee ook die heerlikheid wat Hy van die Vader ontvang, aan sy dissipels (17:22). Hierdie heerlikheid is daarin geleë dat die dissipels een is met mekaar en dat Christus in hulle is soos die Vader in Christus is, sodat die wêreld kan weet dat die Vader hulle liefhet soos Hy Christus liefhet (17:23). Christus spreek ook die wens teenoor die Vader uit dat sy volgelinge by Hom sal wees sodat hulle sy heerlikheid sal aanskou (17:24). Jesus het nie gekom om gedien te word nie, maar om te dien en sy lewe te gee as losprys vir baie. Daardeur verheerlik Hy die Vader, en omdat Hy die Vader verheerlik, verheerlik die Vader Hom ook. So is dit ook met die diakonos van Jesus: die wat Hom volg en dien, verheerlik Jesus en die Vader deur hulle dienswerk, en hulle sal ook deur die Vader verheerlik word met die heerlikheid van Christus (Breed 2012c; Thomas 2004:80; Van der Watt 2008:91).

Die doel van die diakonia aan en deur kinders is die verheerliking van God in die afwagting van die verheerliking deur God. Diakonia aan kinders is begeleiding tot volkome toewyding aan God en mekaar. Alle diakonia is in die eerste plek gerig op die verheerliking van God en nie 'n blote aksie van medemenslikheid nie (Van der Watt 2008:90-93). Die diakonia aan mense is in die eerste plek gehoorsaamheid aan die opdrag van God wat uitmond in liefde vir jou naaste. Die kind wat deur die gemeente en sy ouers bedien word met die genade van God, leer begryp wat dit beteken dat God vír hulle en nie téén hulle is nie (Hendriks \& Grobbelaar 2009b:362, 363). Hulle leer begryp wat dit beteken om nou deur God verheerlik te word en op pad te wees na volkome heerlikheid. Die gemeente wat God dien deur ook mekaar te bedien, word deel van die wederkerige verheerliking wat daar tussen die Vader en die Seun en elke diakonos van Christusbestaan. Die kind en ouer wat begelei word om te dien soos Christus gedien het, kan die gesindheid van Christus teenoor ander uitleef en dit so deel maak van hulle lewe. Volwasse mentors speel hierin 'n baie belangrike rol in die kind se lewe (Lanker \& Issler 2010:93, 94). Indien die kind saam met verskeie mentors by diakonia betrokke is, het dit ' $n$ ingrypende positiewe inpak op sy geloofslewe.

\section{Diakonia en identiteit}

Paulus gebruik die woord diakonos telkens om sy identiteit in Christus en ook die identiteit van ander wat in diens van Christus staan, te beskryf (Ef 3:7; Ef 6:21; Kol 1:7; Kol 1:23; Kol 1:25; Kol 4:7; 1 Tess 3:2; 1 Tim 4:6; 1 Kor 3:5; 2 Kor 3:6; 2 Kor 6:4).

Die kind en ouer moet hulleself in hulle identiteit as gesante en verteenwoordigers van God leer ken (Latvus 2008:145, 146). Waar kinders en jongmense soekend is na identiteit, dien aktiewe toerusting vir en betrokkenheid in diakonia om 'n identiteit te vestig wat buite hulleself en hulle omstandigheid lê. Dit is die identiteit as diakonos van Christus wat God verheerlik en deur God verheerlik sal word. Natale (1979:246) verwoord die belang van die gesin in identiteitsvorming soos volg: 'The family is the primary arena of experience and as such is the mediator of developing an authentic self. It is the matrix of identity.'

In die huisgesin maak die kind ' $n$ bepaalde lewens- en wêreldbeskouing deel van sy verhouding tot die wêreld, ander mense en God (Mueller 2006:58-60). Sien hy homself as een wat bedien moet word, of een wat dien? Sien hy homself as iemand wat nie veel het om aan ander te bied nie, of as 'n begenadigde van God wat die rykdom van God se genade moet bestuur en aan ander uitdeel deur sy diakonia? 'n Kind wat van kleins af leer om ander te dien, leer ook van kleins af die rykdom van sy gawes en ervaar die vreugde om God se genade in ander mense se lewe in te dra sodat sy koninkryk daar realiseer (Anderson 2001:233-249). So word sy identiteit as diakonos iets wat hom nederig maak en tog aan hom 'n bewussyn gee van sy onskatbare waarde in Christus deur die werk van die Gees. Hierdie begrip van sy identiteit as diakonos maak hom weerbaar teen groepsdruk. Kinders wat nie hulle waarde in Christus vind nie, soek hulle identiteit in die aanvaarding deur maats, hulle prestasies of hulle opstand teen die stelsel. Hierdie dinge kan egter die gevaar loop om van hulle weggeneem te word. Dan voel dit asof hulle totale identiteit bedreig word. Dit maak hulle vatbaar vir groepsdruk om kosbaarhede van hulle lewe op te offer ter wille van aanvaarding (Mueller 2007:248-256). Die gemeente moet gesinne, ook gebroke gesinne, bystaan en toerus om doelbewus hierdie identiteit te vorm (Barnhill 2010:23, 24). 


\section{Gevolgtrekking}

Doelbewuste begeleiding en toerusting van kinders tot dienswerk kan 'n belangrike rol speel om die gesindheid van Christus by kinders en ouers te kweek. Alhoewel baie navorsers op die een of ander manier hierna verwys, is hierdie navorsingsveld nog grootliks onontgin. Die belangrikheid van ouers se rol in die begeleiding van kinders word vanuit verskillende navorsingsvelde beklemtoon. Ouers en ander rolmodelle moet begelei en toegerus word om hulle unieke geleentheid en gawes te gebruik om hulle dienswerk (diakonia) teenoor kinders te verrig. Hierin het die kerk 'n unieke geleentheid en opdrag. Wanneer 'n kind toegerus en begelei word om sy of haar gawes in praktiese dienswerk te laat oorgaan, kan hy of sy nie neutraal bly nie. Omdat diakonia die bediening van God se genade is, vra dit dat jy in afhanklikheid van God sal leef. Diakonia vloei voort uit ' $n$ bepaalde identiteit, naamlik gestuurde en begenadigde van God. Diakonia is gerig op die verheerliking van God in die verwagting van die verheerliking deur God. Wanneer klem geplaas word op die noodsaaklikheid dat geloof tot dade sal oorgaan, word elkeen wat sê hy of sy glo, voor 'n ingrypende keuse geplaas.

Begeleiding en toerusting tot dienswerk kan ' $n$ kragtige instrument in die hande van die Heilige Gees wees om die gesindheid van Christus in gelowige ouers en kinders te kweek - of hulle te laat besluit om nie deel te hê aan die kerk en die Here van die kerk nie.

Begeleiding en toerusting tot dienswerk maak die krag en genade van God, wat Hy deur die gawes aan die gemeente skenk, effektief in die lewe van elke diakonos van Christus wat dien en gedien word.

\section{Erkenning \\ Mededingende belange}

Die outeurs verklaar dat hulle geen finansiële of persoonlike verbintenis het met enige party wat hulle nadelig kon beïnvloed in die skryf van hierdie artikel nie.

\section{Outeursbydrae}

F.P.K. (Noordwes-Universiteit) het die navorsing vir deel 1-3 van die artikel gedoen en dit geskryf. G.B. (NoordwesUniversiteit) het die navorsing vir deel $4-5$ van die artikel gedoen en dit geskryf.

\section{Literatuurverwysings}

Anderson, R.S., 2001, The shape of practical theology. Empowering ministry with theological praxis, IVP Academic, Downers Grove, IL.

Arndt, W., Danker, F.W. \& Bauer, W., 2000, A Greek-English lexicon of the New Testament and other early Christian literature: Based on Walter Baur's Griechisches-Deutsches Wörterbuch zu den Schriften des Neuen Testaments und der übrigen urchristlichen Literatur, 3rd rev. edn., University of Chicago Press, Chicago, IL.

Asumang, A., 2012, 'Modelling the Gospel in joyful partnership: Exemplars and the uniting theme of Philippians', The Journal of the South African Theological Seminary 13, 1-50.

Barnhill, C., 2010, 'Coming alongside parents', Christianity Today 54(7), 23-24.

Baron, R.A. \& Byrne, D., 1994, Social psychology, Allyn \& Bycan, MA.
Blumberg, S.H., 2006, 'Repairing the world: The pace of Mitzvot in children's spiritual live', in K.M. Yust (ed.), Nurturing child and adolescent spirituality: Perspectives from the world's religious traditions, pp. 275-284, Rowman \& Littlefield, Lanham, MD.

Boshoff, H., 1985, Die kerkjeug antwoord, NG Kerkboekhandel, Pretoria.

Breed, G., 1994, 'Kategese en geloofsopvoeding', ThD-proefskrif, Fakulteit Teologie, PU vir CHO, Potchefstroom.

Breed, G., 2012a, "n Begronde bedieningsmodel vir die diakonia van die gemeente', HTS Teologiese Studies/Theological Studies 68(2), 1-11. http://dx.doi.org/10.4102/ HTS Teologiese
hts.v68i2.1107

Breed, G., 2012b, 'Nuut gedink oor die wese en inhoud van die dienswerk van die diaken', HTS Teologiese Studies/Theological Studies 68(1), 1-8. http://dx.doi. org/10.4102/hts.v68i1.1059

Breed, G., 2012c, 'Viva vox Evangelii - reforming preaching, The preacher as diakonos according to John 12:26', unpublished paper delivered at Societas Homiletica, Wittenberg, 10-15 August.

Breed, G. \& Breed, D.G., 2010, 'Besinning oor die diakonale dienswerk na aanleiding van Handelinge 6:1-7', In die Skriflig/ In Luce Verbi 44(3/4), 627-653. http://dx.doi. org/10.4102/ids.v44i3/4.165

Bruce, F.F., 2011, Philippians, Baker Books, Grand Rapids, MI. (Understanding the Bible Commentary Series).

Bunge, M.J., 2008, 'Biblical and theological perspectives on children, parents, and "best practices" for faith formation: Resources for child, youth, and family ministry today', Dialog: A Journal of Theology 47(4), 348-360. http://dx.doi.org/10.1111/ j.1540-6385.2008.00414.x

Cartledge, M.J., 2003, Practical theology - Charismatic and empirical perspectives, Paternoster, London.

Collins, J.N., 1990, Diakonia, re-interpreting the ancient sources, Oxford University Press, Oxford.

Collins, J.N., 1995, 'A ministry for tomorrow's church', Journal of Ecumenical Studies $32(2), 159-178$.

Collins, J.N., 2002a, Deacons and the church: Making connections between old and new, Gracewing Publishing, Herefordshire.

Collins, J.N., 2002b, 'Contextualising Dorothea Reininger's women deacons', in Woman can be priests, viewed 13 October 2008, from http://www.womenpriests.org/ called/collins3.asp

Collins, J.N., 2005, 'Fitting lay ministries into a theology of ministry, responding to an American consensus', Worship 79(2), 152-167.

Collins, J.N., 2010, 'Re-thinking "eyewitnesses" in the light of "servants of the word" (Luke 1:2)', Expository Times 121(9), 447-452. http://dx.doi.org/10.1177/ 0014524610366500

Dames, G.E., 2006, 'Praktiese kategese vir'n postmoderne geloofsgemeenskap: Ploeger se godsdienspedagogiese metodologie vir praktiese kategese', Praktiese Teologie in Suid-Afrika 21(1), 19-38.

Dean, K.D., 2010, Almost Christian: What the faith of our teenagers is telling the American church, Oxford University Press, Oxford.

De Klerk, B.J. \& Dreyer, T.F., 2007, 'Die rol van die gemeente as geloofsgemeenskap in die begeleiding tot belydenisaflegging', In die Skriflig/In Luce Verbi 41(2), 209-231. http://dx.doi.org/10.4102/ids.v41i2.303

De Klerk, B.J. \& Erasmus, J.A., 2003, 'Die plek van jeugbediening binne gemeentebou', In die Skriflig/In Luce Verbi 37(1), 73-95. http://dx.doi.org/10.4102/ids.v37i1.459

De Vries, M., 1997, 'What is youth ministry's relationship to the family?', in R.R. Dunn \& M.H. Senter (eds.), A comprehensive guide to youth ministry, reaching a generation for Christ, pp. 479-502, Moody Publishers, Chicago, IL.

Dingemans, G.D.J. 1991, In de leerschool van het geloof, J.H. Kok, Kampen.

Dreyer, J.M. \& Kruger, F.P., 2011, 'Die ontwerp van 'n kategesekurrikulum vir Graad 1-3 in die Gereformeerde Kerke in Suid-Afrika', Koers - Bulletin for Christian Scholarship 76(2), 325-355. http://dx.doi.org/10.4102/koers.v76i2.19

Duncan, N., 2004, Psychology: An introduction, University Press, Oxford.

Dunn, J.D.G., 2006, The theology of Paul the Apostle, Eerdmans, Grand Rapids, MI.

Dunn, R.R. \& Senter M.H., 1997, Reaching a generation for Christ: A comprehensive guide to youth ministry, Moody Publishers, Chicago, IL.

Du Plessis, A.L. \& Breed, G., 2013, 'A possible solution for corruption in South Africa with the church as initiator: A practical theological approach', HTS Teologiese Studies/ Theological Studies 69(2), Art. \#1298, 10 pages. http://dx.doi.org/10.4102/hts. v69i2.1298

Eagly, A.H. \& Chaiken, S., 1993, The psychology of attitudes, Harcort Brace \& Jovanovich, San Diego, CA.

Feldmeier, R., 2008, The first letter of Peter: A commentary on the Greek text, Baylor University Press, Waco, TX.

Fiske, S.T., 2004, Social beings: A core motives approach to Social Psychology, John Wiley \& Sons, New York, NY.

Goheen, M.W., 2011, A light to the nations: The missional church and the Biblical story, Baker, Grand Rapids, MI.

Gooder, P., 2006, 'Diakonia in the New Testament: A dialogue with John N. Collins', Ecclesiology 3(1), 33-56. http://dx.doi.org/10.1177/1744136606067678

Groeschell, C., 2010, The Christian atheist: When you believe in God but live as if he doesn't exist, Zondervan, Grand Rapids, MI.

Grobbelaar, J. 2008, "n Ondersoek na die bediening van laerskoolkinders in en deur die gemeente as intergenerasionele ruimte', DTh-proefskrif, Fakulteit Teologie, Universiteit van Stellenbosch, Stellenbosch.

Grobbelaar, J. \& Hendriks, H.J., 2006, 'Wat gebeur globaal en plaaslik met kinders', Praktiese Teologie in Suid-Afrika 21(2), 2-32. 
Haire, J. \& Watson, G., 2003, 'Authority and integrity in the ministry of the church', Pronema 18, 29-53.

Hendriks, H.J. \& Grobbelaar, J., 2009a, 'Op soek na 'n nuwe wyse om kinderbediening in en deur die gemeente te verstaan', Nederduitse Gereformeerde Teologiese Tydskrif $50(3 / 4), 350-359$

Hendriks, H.J. \& Grobbelaar, J., 2009b, 'Tendense in kinderbediening aan die begin van die 21ste eeu', Nederduitse Gereformeerde Teologiese Tydskrif 50(3/4), 360-370.

Hentschel, A., 2007, Diakonia im Neuen Testament: Studien zur Semantik unter besonderer Berücksichtigung der Rolle von Frauen, Mohr Siebeck, Tübingen.

Heyns, L.M. \& Pieterse, H.J.C., 1990, Eerste treë in die Praktiese Teologie, Promedia, Pretoria.

Humphrey, B. \& Stokes, J., 2000, The twenty first century supervisor, Jossey Bass \& Pheiffer, San Francisco, CA.

Janse van Rensburg, F., 2011, 'Constructing the economic-historic context of 1 Peter Exploring a methodology', HTS Teologiese Studies/Theological Studies 67(1), 1-11. http://dx.doi.org/10.4102/hts.v67i1.939

Joubert, S., 2009, Jesus ' $n$ radikale sprong, Christelike Uitgewersmaatskappy, Vereeniging

Kennedy, J.W., 2004, 'The 4-14 window: New push on child evangelism targets the crucial early years', Christianity Today 48(7), 53.

Kruger, S.J., 2005, 'Toerusting as wordingsproses: perspektiewe uit die Efesiërbrief', In die Skriflig/In Luce Verbi 39(3), 527-553. http://dx.doi.org/10.4102/ids.v39i3.401

Lanker, J. \& Issler, K., 2010, 'The relationship between natural mentoring and spirituality in Christian adolescents', The Journal of Youth Ministry 9(1), 92-109.

Latvus, K., 2008, 'The paradigm challenged: New analysis of the origin of diakonia', Studia Theologica 62, 142-157. http://dx.doi.org/10.1080/00393380802559816

Latvus, K., 2010, 'Diaconal ministry in the light of the reception and re-interpretation of Acts 6 . Did John Calvin create the social-caritative ministry of diaconia?', Diaconia $1,82-102$.

Lincoln, A.T., 1990, Ephesians, Word Books, Dallas, TX. (Word Biblical Commentary, vol. 42).

Lord, C.G., 1997, Social psychology, Harcourt Brace \& Company, Orlando, FL.

Louw, D. \& Edwards, D., 1998, Sielkunde. 'n Inleiding vir studente in Suider-Afrika, Heinemann Voortgesette Onderwys, Sandton.

Louw, D., \& Louw, A., 2007, Die ontwikkeling van die kind en die adolessent, ABC Drukkers, Bloemfontein.

Marshall, C. \& Payne, T., 2009, The trellis and the vine, Mathias Media, Kingsford.

Mueller, W., 2006, Engaging the soul of youth culture, IVP Books, Downers Grove, IL.

Mueller, W., 2007, Youth culture 101, Zondervan, Grand Rapids, MI.

Natale, S.M., 1979, 'A family systems approach to religious education and development', Religious Education 74(3), 245-253. http://dx.doi.org/10.1080/0034408790740304

$\mathrm{Nel}, \mathrm{M} ., 1982$, Jeug en evangelisasie, NG Kerkboekhandel, Pretoria.

$\mathrm{Nel}, \mathrm{M} ., 2003$, Youth ministry the challenge of individuation', Praktiese Teologie in Suid-Afrika 18(1), 151-196.
Osmer, R., 2009, 'Practical theology: A current international perspective', paper delivered at the Annual conference for the Society for Practical Theology in South Africa, Pretoria, 21 January.

Osmer, R., 2001, 'A checklist for the journey: Biblical foundations of ministry with youth', in T.M. Beaudion (ed.), Proclaiming the Gospel in a wired world, pp. 106-108, The Institute for Youth Ministry, Princeton, NJ.

Pieterse, H.J.C., Dreyer, J.S. \& Van Der Ven, J.A., 2000, 'Images of Jesus among South African youth', Praktiese Teologie in Suid-Afrika 15(1), 53-81.

Pieterse, H.J.C., 2001, Prediking in 'n konteks van armoede, UNISA, Pretoria.

Prins, J.M.G., 2000, 'Die godsdienstige houdings van kerklike betrokke tieners', Praktiese Teologie in Suid-Afrika 15(1), 82-100.

Prins, J.M.G., 2001, 'Intensionele morele vorming,' Praktiese Teologie in Suid-Afrika $16(1), 105-120$.

Prins, J.M.G., 2003, 'Ministering hope: An essential ingredient in youth ministry', Praktiese Teologie in Suid-Afrika 18(2), 143-158.

Robins, D., 1990, The ministry of nurture. A youthworker's guide to discipling teenagers, Zondervan, Grand Rapids, MI.

Robins, D., 2004, This way to youth ministry. An introduction to the adventure, Zondervan, Grand Rapids, MI.

Roebben, B., 1995, Een tijd van opvoeden, Acco, Leuven.

Silva, M., 2005, Philippians, Baker Academic, Grand Rapids, MI.

Smith, J., 2007, "n Gebrek aan jong profete jaag kerklike storms op', in S. Joubert, J. van der Watt, I. Sweet, B. Easum, N. Niemandt (reds.), Die perfekte storm, bl. 131-143, CUM Boeke, Vereeniging.

Strommen, M.P \& Hardel, R.A., 2000, Passing on the faith. A radical new model for youth and family ministry, Saint Mary's Press, Wimona, MN.

Strommen, M.P. \& Hardel, R.A., 2008, Passing on the faith. A radical model for youth and family ministry, rev. edn., Saint Mary's Press, Winona, MN.

Sweet, L., 2007, 'Sal die kerk van die toekoms oorleef?', in S. Joubert, J. van der Watt, I. Sweet, B. Easum \& N. Niemandt (reds.), Die perfekte storm, bl. 15-44, Christelike Uitgewersmaatskappy, Vereeniging.

Thomas, J.C., 2004, Footwashing in John 13 and the Johannine community, T\&T Clark, London.

Tripp, T., 2007, Shepherding a child's heart, Shepherd Press, Wapwallopen, PY.

Van der Watt, J., 2008, 'Johannine style: Some initial remarks on the functional use of repetition in the Gospel according to John', In die Skriflig/In Luce Verbi 42(1), 75-99. http://dx.doi.org/10.4102/ids.v42i1.258

Van Klinken, J., 1989, Diakonia, J.H. Kok, Kampen.

Van Wyk, G. \& Venter, C.J.H., 2003, 'Die gelowige ouer as geloofsvoorbeeld. Praktiesteologiese perspektiewe op toerusting', In die Skriflig/In Luce Verbi 37(3), 533-553. http://dx.doi.org/10.4102/ids.v37i3.481

Wood, S.E. \& Wood, E.G., 1999, The world psychology, Allyn \& Bacon, Boston, MA.

Woolfolk, A., 2007, Educational psychology, Pearson, Boston, MA. 